\title{
Technical Efficiency of Small Scale Food and Beverage Enterprise of Female Entrepreneurs in Bantul using Data Envelopment Analysis (DEA)
}

\author{
Ummu Harmain \\ Faculty of Agriculture \\ Simalungun University, \\ Pematangsiantar, Indonesia
}

\author{
Slamet Hartono \\ Faculty of Agriculture \\ Gadjah Mada University, \\ Yogyakarta, Indonesia
}

\author{
Dwidjono H. D \\ Faculty of Agriculture \\ Gadjah Mada University, \\ Yogyakarta, Indonesia
}

\begin{abstract}
Thirty five female entrepreneurs of food and beverage subsector in Bantul district were interviewed to find out the efficiency of the business they operated. All of the businesses were of the kind of micro and small enterprises. Analysis was made using data envelopment analysis (DEA). The results of the analysis showed that there were 9 efficient small scale enterprises (SSE) and the remaining was inefficient. The mean technical efficiency was 0.79 . Overall, there were 3 SSE in a condition of constant return to scale, 3 SSE in a condition of increasing return to scale and 29 SSE in a condition of decreasing return to scale. It was possible for the inefficient SSE to reach efficiency level by decreasing input and increasing output as recommended.
\end{abstract}

\section{General Terms}

Agribusiness Management.

\section{Keywords}

Female entrepreneurs, efficiency, small scale enterprise (SSE), data envelopment analysis (DEA).

\section{INTRODUCTION}

In the past decades there has been an increase in the number of females who were self-employed, built and operated their own businesses. Global Entrepreneurship Monitor (2012) reported that there were 126 millions of females who began their businesses, while 98 other females have operated their own businesses for at least 3.5 years. Based on the report there were at least 224 million businesses operated by females. The number would increase if all countries were included because the GEM included only 67 countries [1].

In the past few years the number of females who owned businesses in United States of America increased dramatically. In 1997, there were 8.5 million females who owned their own businesses. The number represented one third of all of the existing businesses in the district. There were 23.8 million labors absorbed. In the period of 1987-1997 there has been significant increase $(262 \%)$ in the number of the labors [2]. According to the data of Kementerian Pemberdayaan Perempuan dan Perlindungan Anak Republik Indonesia (2011) there were 46 million small and medium enterprises in Indonesia, some of them were home industries. About $60 \%$ of the home industry managers were women. Concerning with the significant number, the role of the women was very dominant in economic endurance because they were able to create employment, to produce products and services at affordable price and to alleviate poverty [3].

The increase in the number of the women that owned the businesses resulted from some factors, which were among others their independence and their need to seek self- achievement [4], [5], flexibility [6], autonomy and financial needs [7], [8] and environment [9].

Though the growth rate of the businesses of the women was higher than that of the businesses of men, quantitatively it was still relative small. The size of the businesses of the women tended to be small as compared to that of the businesses of the men and concentrated in service and retail sectors. Additionally, Singh et. al. (2001) suggested that their businesses in Indonesia concentrated in informal sector with low income in which $78.8 \%$ of them was in food processing subsector [10]. There was indication that the number of the female entrepreneurs in Indonesia was more likely to decrease related to the size of their businesses [8].

The businesses owned by women had higher failure level, while the selling rate, the profitability and the number of labors were lower than those of the businesses of men [11]. The activity space was smaller than that in the past and it was more likely to slow down [12]. The characteristics and the responsibility for family were in fact insignificant as compared to the responsibility for the performance of their businesses [13].

The problems facing them related in general to the businesses/the entrepreneurship, social and technical aspects. According to Minniti and Win (2010) it resulted from the behavior of the female entrepreneurs related to characteristics, motivation, success level and the difference in gender that were complex and multifaceted in nature [14]. They would have negative impact on working efficiency [15], [16] and business performance.

Based on the aforementioned data, the study of the efficiency of the businesses owned by female entrepreneurs could provide more complete description of their businesses. The study would examine the efficiency level of the businesses and give recommendations for efficient operation of the businesses.

\section{LITERATUR REVIEW}

\subsection{The Previous Studies}

There have been many studies related to the efficiency of the small and medium enterprise (SME). One of them was the study by Batra and Tan (2003) of the small and medium manufacture enterprise in six developing countries. The results showed that the size of the businesses was not directly proportional to the efficiency level. Some small firms had equal and even higher efficiency than the bigger ones. The causal factors of the difference were training and education, investment in new technology, automation and quality control [17]. Subsequently, Bhasin (2009) concluded that there was still wide enough space for the female entrepreneurs in food and beverage business to improve technical efficiency in Cape 
Coast with the mean value of the technical efficiency of $64.5 \%$ [18]. Heilbrunn, Rozenes and Vitner (2011) suggested that there were 89 small and medium enterprise of 248 small and medium enterprise in Israel, which were efficient and concentrated in general on decreasing the cost of their business activities [19]. Charoenrat, Harvie and Naburana (2013) measured the technical efficiency of the small and medium manufacture enterprise in Thailand using stochastic frontier analysis (SFA) and data envelopment analysis (DEA). The results showed that the mean technical efficiency was relative low [20]. Purwanto, Mangongga and Pakereng (2014) conducted a study of small and medium businesses in Salatiga. The results showed that there were 8 small and medium businesses of 31 small and medium businesses, which were efficient [21].

\subsection{The Definition of Small Scale Enterprise (SSE)}

Based on Undang-undang Republic Indonesia number 20/2008 on micro, small and medium enterprise, small scale enterprise (SSE) was independent productive economic enterprise operated by individuals or business entity that was not subsidiary owned, controlled or direct or indirect part of the medium or big business as intended in the act [22]. The criteria of small sale enterprise according to the act were summarized in the following table:

Table 1. SSE Income Criteria (Million Rp)

\begin{tabular}{|l|c|c|c|c|}
\hline \multirow{2}{*}{$\begin{array}{c}\text { Enterpri } \\
\text { se } \\
\text { Criteria }\end{array}$} & \multicolumn{2}{|c|}{ Net Assets (IDR) } & \multicolumn{2}{c|}{ Annual Sales (IDR) } \\
\cline { 2 - 5 } & Min & Max & Min & Max \\
\hline Micro & - & 50 & - & 300 \\
\hline Small & 50 & 500 & 300 & 2,500 \\
\hline
\end{tabular}

Source: Undang-undang RI no 20 Tahun 2008

\subsection{Data Envelopment Analysis (DEA)}

Data envelopment analysis (DEA) was applied in measuring efficiency in this research. The DEA was non-parametric frontier mathematic program [23] that used linear program model to calculate output-input ratio for all of the units in a population. It aimed at measuring relative efficiency level of decision making unit (DMU) of similar activities when all of the units were on or under the frontier efficiency curve. Decision making unit (DMU) was used to avoid the difference in the terms used by organizational entities related to the decision on input and output in economic literature [24]. The analysis was designed to measure relative efficiency of production unit many input and output [25]. There were many models in the DEA. Charnes, Cooper and Rhodes suggested an input-oriented model and assumed constant return to scale (CRS) model. The CRS aimed at maximizing output. The formula was as follow:

$$
\begin{aligned}
& \max _{\mu_{k} v_{i}} \sum_{k=1}^{p} \mu_{k} y_{k 0} \\
& \text { s.t } \quad \sum_{i=1}^{m} v_{i} x_{i 0}=1 \\
& \sum_{k=1}^{p} \mu_{k} y_{k 0}-\sum_{i=1}^{m} \mathrm{v}_{\mathrm{i}} \mathrm{x}_{\mathrm{ij}} \leq 0 \\
& \mathrm{j}=1, \ldots, \mathrm{n} \quad \mathrm{k}=1, \ldots, \mathrm{p}
\end{aligned}
$$

$$
\mu_{k} \geq \varepsilon, v_{i} \geq \varepsilon \quad \mathrm{i}=1, \ldots, \mathrm{m}
$$

Then, Banker, Charnes and Cooper (1984) proposed variable return to scale (VRS) model. The model assumed that a business has not operated at maximal scale, meaning that its input and output did not equal. In other words, the increase in the input (x) would not surely cause the increase in the output (x), which might be bigger or smaller [26]. Its formula was as follow:

$$
\begin{array}{ll}
\max _{\mu_{k} v_{i}} & \sum_{k=1}^{p} \mu_{k} y_{k 0}-u_{0} \\
\text { s.t } \quad & \sum_{i=1}^{m} v_{i} x_{i 0}=1 \\
& \sum_{k=1}^{p} \mu_{k} y_{k j}-\sum_{i=1}^{m} v_{i} x_{i j}-u_{0} \leq 0 \quad j=1, \ldots, n \\
& k=1, \ldots, p \quad \mu_{k} \geq \varepsilon, v_{i} \geq \varepsilon \quad i=1, \ldots, m
\end{array}
$$

Where

$\mathrm{y}=$ input of SSE

$\mathrm{x}=$ output of SSE

$\mathrm{vi}=$ non negative scalars

$\mu_{\mathrm{k}}=$ unit price of output $\mathrm{k}$ of SSE

$\mathrm{k}=\mathrm{p}^{\text {th }}$ output

$\mathrm{i}=\mathrm{m}^{\text {th }}$ input

$\mathrm{y}_{\mathrm{ko}}=\mathrm{k}^{\text {th }}$ input that maximize cost for SSE

$\mathrm{x}_{\mathrm{io}}=\mathrm{p}^{\text {th }}$ input for $\mathrm{m}^{\text {th }} \mathrm{SSE}$

\section{THE RESEARCH METHODOLOGY}

Respondents were 35 female entrepreneurs in food and beverage in Bantul district. They operated businesses categorized as small scale enterprise (SSE). The input data included raw material cost and labor cost, while the output included income and gross margin. The data were analyzed using DEA SOLVER software.

\section{FINDINGS}

\subsection{Data Analysis}

Efficiency value, ranking and return to scale of the SSE could be found in table 2 .

Table 2. Score, Rank and RTS of SSE

\begin{tabular}{|r|l|r|c|}
\hline \multicolumn{1}{|c|}{ SSE } & Score & \multicolumn{1}{c|}{ Rank } & RTS \\
\hline 29 & 1 & 1 & Decreasing \\
\hline 1 & 1 & 1 & Decreasing \\
\hline 28 & 1 & 1 & Constant \\
\hline 27 & 1 & 1 & Constant \\
\hline 4 & 1 & 1 & Constant \\
\hline 26 & 1 & 1 & 1 \\
\hline
\end{tabular}




\begin{tabular}{|c|c|c|c|}
\hline 23 & 1 & 1 & Decreasing \\
\hline 18 & 1 & 1 & Decreasing \\
\hline 13 & 1 & 1 & Decreasing \\
\hline 12 & 0.942895 & 10 & Decreasing \\
\hline 17 & 0.937082 & 11 & Decreasing \\
\hline 6 & 0.936631 & 12 & Decreasing \\
\hline 35 & 0.931814 & 13 & Decreasing \\
\hline 8 & 0.915063 & 14 & Decreasing \\
\hline 16 & 0.902175 & 15 & Decreasing \\
\hline 22 & 0.889017 & 16 & Decreasing \\
\hline 15 & 0.884118 & 17 & Decreasing \\
\hline 25 & 0.874658 & 18 & Decreasing \\
\hline 7 & 0.848442 & 19 & Decreasing \\
\hline 32 & 0.777558 & 20 & Decreasing \\
\hline 31 & 0.757362 & 21 & Decreasing \\
\hline 34 & 0.743464 & 22 & Decreasing \\
\hline 14 & 0.736093 & 23 & Decreasing \\
\hline 21 & 0.677182 & 24 & Decreasing \\
\hline 33 & 0.637045 & 25 & Decreasing \\
\hline 3 & 0.625973 & 26 & Increasing \\
\hline 19 & 0.598639 & 27 & Decreasing \\
\hline 24 & 0.583676 & 28 & Increasing \\
\hline 30 & 0.565435 & 29 & Decreasing \\
\hline 5 & 0.535241 & 30 & Decreasing \\
\hline 10 & 0.528597 & 31 & Decreasing \\
\hline 20 & 0.523585 & 32 & Decreasing \\
\hline 9 & 0.489675 & 33 & Decreasing \\
\hline 11 & 0.475397 & 34 & Decreasing \\
\hline 2 & 0.471942 & 35 & Decreasing \\
\hline mean & \multicolumn{3}{|c|}{0.7939} \\
\hline
\end{tabular}

It was clearly observed in the table 2 that the highest efficiency value was 1 for the SSE 29, 1, 28, 27, 4, 26, 23, 18 and 13. The lowest efficiency value was 0.472 for the SSE 2 . The mean efficiency was 0.7939. Based on the efficiency value the distribution of the efficiency values of the SSE were summarized in table 3 .

Table 3. Distribution of Production Efficiency Level of SSE

\begin{tabular}{|c|c|}
\hline score & SSE \\
\hline 1 & 9 \\
\hline $0.9-0.99$ & 6 \\
\hline $0.8-0.89$ & 4 \\
\hline $0.7-0.79$ & 3 \\
\hline $0.6-0.69$ & 6 \\
\hline $0.5-0.59$ & 3 \\
\hline $0.4-0.49$ & 35 \\
\hline Total & 4 \\
\hline
\end{tabular}

Based on the distribution of the efficiency scores it was observed that the highest value was 1 , which was for the SSE 9 , while the lowest value was in the interval 0.40-0.49 and 0.6-0.69 for SSE 3.

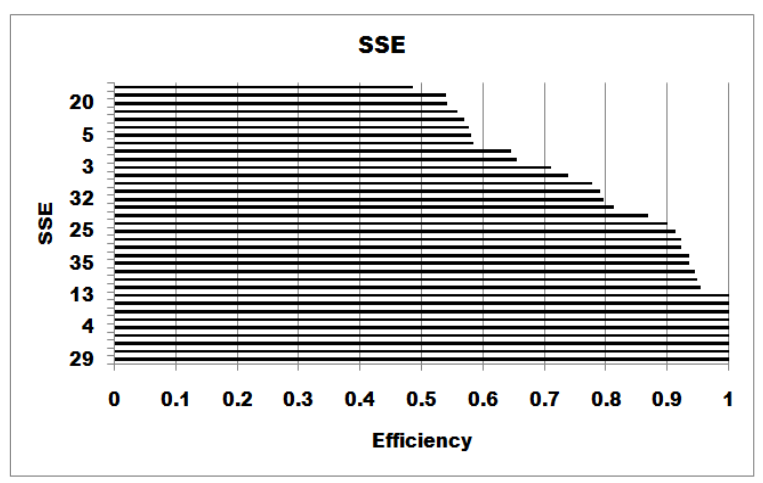

Figure 1. Efficiency Value of SSE by Rank

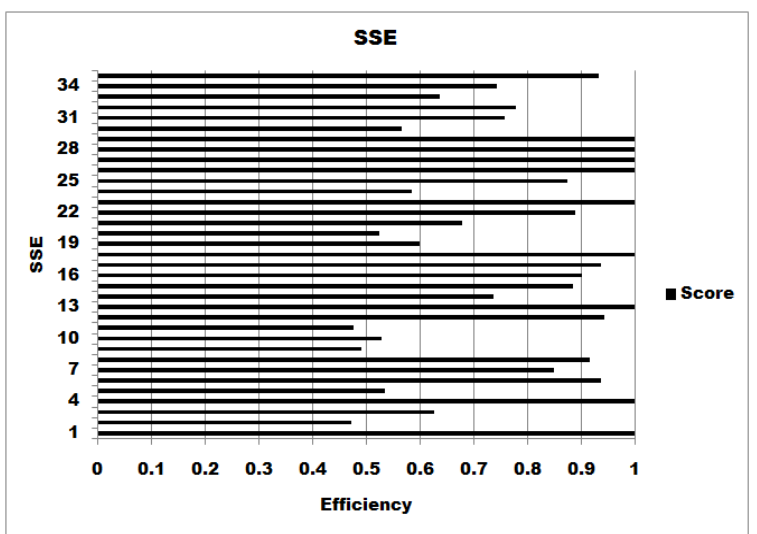

Figure 2. Efficiency Value of SSE by Score 
Tabel 4. RTS SSE

\begin{tabular}{|c|r|r|r|}
\hline RTS & Efficient & \multicolumn{1}{|c|}{ Projected } & \multicolumn{1}{|c|}{ Total } \\
\hline No. of IRS & 1 & 2 & 3 \\
\hline No. of CRS & 3 & 0 & 3 \\
\hline No. of DRS & 5 & 24 & 29 \\
\hline Total & 9 & 26 & 35 \\
\hline
\end{tabular}

Based on figure 1, 2 and table 4 above, it can be shown that there were 9 efficient SSE and the remaining 26 SSE. There were three SSE of the efficient businesses in constant return to scale category, a SSE in increasing return to scale category, and 5 SSE in decreasing return to scale category. Meanwhile, there were 2 SSE out of 29 inefficient SSE in increasing return to scale category, while the remaining 24 SSE were in decreasing return to scale category. In general, there were 3 SSE in the constant return to scale category, 3 SSE in the increasing return to scale category and 29 SSE in the decreasing return to scale category.

\subsection{Development Scenario based on the Efficiency Value}

The small scale enterprise in the increasing return to scale category indicated that it was still possible for them to achieve efficiency by increasing input, while the SSE in the decreasing return to scale category showed that they had to decrease the use of the input to achieve improve the condition. The recommendations for each SSE to achieve efficiency were presented in table below.

Table 5. Recommendations for SSE to Achieve Efficiency

\begin{tabular}{|c|l|l|}
\hline SSE & \multicolumn{1}{|c|}{ I/O } & \multicolumn{1}{c|}{ Recommends } \\
\hline 2 & Raw material & Lessen up to 52.81\% \\
& Mabor & Lessen up to 52.8\% \\
Improve up to $266.51 \%$
\end{tabular}

\begin{tabular}{|c|c|c|}
\hline 7 & $\begin{array}{l}\text { Raw material } \\
\text { Labor } \\
\text { Margin }\end{array}$ & $\begin{array}{l}\text { Lessen up to } 15.16 \% \\
\text { Lessen up to } 15.16 \% \\
\text { Improve up to } 170.86 \%\end{array}$ \\
\hline 8 & $\begin{array}{l}\text { Raw material } \\
\text { Labor } \\
\text { Margin }\end{array}$ & $\begin{array}{l}\text { Lessen up to } 8.49 \% \\
\text { Lessen up to } 8.49 \% \\
\text { Improve up to } 28.66 \%\end{array}$ \\
\hline 9 & $\begin{array}{l}\text { Raw material } \\
\text { Labor } \\
\text { Margin }\end{array}$ & $\begin{array}{l}\text { Lessen up to } 51.03 \% \\
\text { Lessen up to } 51.03 \% \\
\text { Improve up to } 269.63 \%\end{array}$ \\
\hline 10 & $\begin{array}{l}\text { Raw material } \\
\text { Labor } \\
\text { Margin }\end{array}$ & $\begin{array}{l}\text { Lessen up to } 47.14 \% \\
\text { Lessen up to } 47.14 \% \\
\text { Improve up to } 161.77 \%\end{array}$ \\
\hline 11 & $\begin{array}{l}\text { Raw material } \\
\text { Labor } \\
\text { Margin }\end{array}$ & $\begin{array}{l}\text { Lessen up to } 52.46 \% \\
\text { Lessen up to } 52.46 \% \\
\text { Improve up to } 269.30 \%\end{array}$ \\
\hline 12 & $\begin{array}{l}\text { Raw material } \\
\text { Labor } \\
\text { Margin }\end{array}$ & $\begin{array}{l}\text { Lessen up to } 5.71 \% \\
\text { Lessen up to } 5.71 \% \\
\text { Improve up } 58.97 \%\end{array}$ \\
\hline 14 & $\begin{array}{l}\text { Raw material } \\
\text { Labor } \\
\text { Margin }\end{array}$ & $\begin{array}{l}\text { Lessen up to } 26.39 \% \\
\text { Lessen up to } 26.39 \% \\
\text { Improve up to } 298.00 \%\end{array}$ \\
\hline 15 & $\begin{array}{l}\text { Raw material } \\
\text { Labor } \\
\text { Margin }\end{array}$ & $\begin{array}{l}\text { Lessen up to } 11.59 \% \\
\text { Lessen up to } 11.59 \% \\
\text { Improve up to } 122.58 \%\end{array}$ \\
\hline 16 & $\begin{array}{l}\text { Raw material } \\
\text { Labor } \\
\text { Margin }\end{array}$ & $\begin{array}{l}\text { Lessen up to } 9.78 \% \\
\text { Lessen up to } 9.78 \% \\
\text { Improve up to } 107.27 \%\end{array}$ \\
\hline 17 & $\begin{array}{l}\text { Raw material } \\
\text { Labor }\end{array}$ & $\begin{array}{l}\text { Lessen up to } 5.71 \% \\
\text { Lessen up to } 5.71 \%\end{array}$ \\
\hline & Margin & Improve up to $58.97 \%$ \\
\hline
\end{tabular}




\begin{tabular}{|c|c|c|}
\hline 19 & $\begin{array}{l}\text { Raw material } \\
\text { Labor } \\
\text { Margin }\end{array}$ & $\begin{array}{l}\text { Lessen up to } 40.14 \% \\
\text { Lessen up to } 40.14 \% \\
\text { Improve up to } 107.49 \%\end{array}$ \\
\hline 20 & $\begin{array}{l}\text { Raw material } \\
\text { Labor } \\
\text { Margin }\end{array}$ & $\begin{array}{l}\text { Lessen up to } 47.64 \% \\
\text { Lessen up to } 47.64 \% \\
\text { Improve up to } 117.27 \%\end{array}$ \\
\hline 21 & $\begin{array}{l}\text { Raw material } \\
\text { Labor } \\
\text { Margin }\end{array}$ & $\begin{array}{l}\text { Lessen up to } 32.28 \% \\
\text { Lessen up to } 32.28 \% \\
\text { Improve up to } 59.11 \%\end{array}$ \\
\hline 22 & $\begin{array}{l}\text { Raw material } \\
\text { Labor } \\
\text { Margin }\end{array}$ & $\begin{array}{l}\text { Lessen up to } 11.10 \% \\
\text { Lessen up to } 11.10 \% \\
\text { Improve up to } 15.04 \%\end{array}$ \\
\hline 24 & $\begin{array}{l}\text { Raw material } \\
\text { Labor } \\
\text { Margin }\end{array}$ & $\begin{array}{l}\text { Lessen up to } 41.63 \% \\
\text { Lessen up to } 41.63 \% \\
\text { Improve up to } 79.13 \%\end{array}$ \\
\hline 25 & $\begin{array}{l}\text { Raw material } \\
\text { Labor } \\
\text { Margin }\end{array}$ & $\begin{array}{l}\text { Lessen up to } 12.53 \% \\
\text { Lessen up to } 12.53 \% \\
\text { Improve up to } 23.81 \%\end{array}$ \\
\hline 30 & $\begin{array}{l}\text { Raw material } \\
\text { Labor } \\
\text { Margin }\end{array}$ & $\begin{array}{l}\text { Lessen up to } 43.46 \% \\
\text { Lessen up to } 43.46 \% \\
\text { Improve up to } 80.70 \%\end{array}$ \\
\hline 31 & $\begin{array}{l}\text { Raw material } \\
\text { Labor } \\
\text { Margin }\end{array}$ & $\begin{array}{l}\text { Lessen up to } 24.26 \% \\
\text { Lessen up to } 24.26 \% \\
\text { Improve up to } 21.88 \%\end{array}$ \\
\hline 32 & $\begin{array}{l}\text { Raw material } \\
\text { Labor } \\
\text { Margin }\end{array}$ & $\begin{array}{l}\text { Lessen up to } 22.24 \% \\
\text { Lessen up to } 22.24 \% \\
\text { Improve up to } 19.57 \%\end{array}$ \\
\hline 33 & $\begin{array}{l}\text { Raw material } \\
\text { Labor } \\
\text { Margin }\end{array}$ & $\begin{array}{l}\text { Lessen up to } 36.30 \% \\
\text { Lessen up to } 36.30 \% \\
\text { Improve up to } 45.66 \%\end{array}$ \\
\hline
\end{tabular}

\begin{tabular}{|l|l|l|}
\hline 34 & Raw material & Lessen up to $25.65 \%$ \\
& Labor & Lessen up to $25.65 \%$ \\
& Margin & Improve up to $31.61 \%$ \\
\hline 35 & Raw material & Lessen up to $6.82 \%$ \\
& Labor & Lessen up to $6.82 \%$ \\
& Improve up to $4.63 \%$ \\
\hline
\end{tabular}

In general, it is necessary for the businesses to decrease the raw material at $20.60 \%(\operatorname{Rp} 2,830,678)$ and the labor at $21.29 \%(\operatorname{Rp~516,306)}$ to achieve the efficiency level. The complete data were summarized in the table below.

Tabel 6. Input changes to production efficiently

\begin{tabular}{|l|r|l|}
\hline & \multicolumn{1}{|c|}{ Raw material } & \multicolumn{1}{l|}{ Labor } \\
\hline Actual & 30922920 & 4221378.57 \\
\hline Differences & -2830678 & -516305.98 \\
\hline Optimal & 28092242 & 3705072.59 \\
\hline
\end{tabular}

\section{CONCLUSIONS}

Technically, there were 9 efficient small scale enterprise (25.71\%) owned by female entrepreneurs in Bantul district, while 26 SSE $(74.29 \%)$ were inefficient. Based on the return to scale there were 3 SSE in constant condition, 3 SSE in increasing condition and 29 SSE in decreasing condition. It was expected that the inefficient SSE could implement the recommendations given for better outcome. For futher, it needs to know the effect of technology used by female entrepreneurs to technical efficiency.

\section{ACKNOWLEDGEMENT}

I would like to deliver thanks to Ditjen DIKTI that has funded part of the study through Grant for Doctoral Dissertation Research from DP2M Ditjen DIKTI.

\section{REFERENCES}

[1] Global Entrepreneurship Monitor 2012 Women's Report.www.gemconsortium.org.

[2] Coleman, Susan (2007) The Role of Human and Financial in the Profitability and Growth of WomenOwned Small Firms. Journal of Small Business Management 45 (3) pp. 303-319.

[3] Kementerian Pemberdayaan Perempuan dan Perlindungan Anak Republik Indonesia (2011) Perempuan dan Industri Rumahan; Pengembangan Industri Rumahan dalam Sistem Ekonomi Rumah Tangga untuk Peningkatan Kualitas Hidup Perempuan dan Anak.

[4] Morrison, A.M, Randall P. White dan Ellen Van Veslor (1992) Breaking The Glass Ceiling: Can Women Reach The Top Of America's Large Corporations? MA: Addison Wesley.

[5] Hisrich, R.D, Brush, C., Good, D and De Souza, G. (1996) Some Preliminary Findings On Performance In 
Entrepreneurial Ventures: Does Gender Matter? Frontiers Of Entrepreneurship Research, April, Babson College, Wellesley, MA.

[6] Ducheneaut, B. and Orhan, M. (2000) Les Femmes Entrepreneur En France: Percee des Femmes dans un Monde Construit au Masculi, Seli Aslan, Paris.

[7] McElwee, Gerard and Rahma Al-Riyami (2003) Women Entrepreneurs In Oman: Some Barriers To Success. Career Development International 8 (7) Pp. 339 - 346.

[8] Tambunan, Tulus (2009) Women Entrepreneurs In Indonesia: Their Main Constraint and Reasons. Journal Of Asia Entrepreneurship and Sustainability, Refereed Edition 5(3): 37-50.

[9] Mansor, Norudin and Azman Che Mat (2010) The Significance Of Psychology and Environment Dimensions For Malaysian Muslim Women Entrepreneurships Venturing. International Journal Of Human Sciences 7 (1): 253-269.

[10] Singh, Surendra P., Reynold, Ruthie G. and Safdar Muhammad (2001) A Gender-Based Performance Analysis Of Micro and Small Enterprises In Java, Indonesia. Journal Of Small Business Management 39(2): 174-182.

[11] Watson, John (2003) Failure Rates For FemaleControlled Business: Are They Any Different? Journal Of Small Business Management 41(3): 262-277.

[12] Robb, Alicia; Susan Coleman and Dane Stangler (2014) Sources Of Economic Hope: Women's Entrepreneurship. Ewing Marion Kauffman Fondation.

[13] Bula, Hannah Orwa (2012) Performance Of Women In Small Scale Entreprises (SSE): Marital Status and Family Characteristics. European Journal Of Business and Management 4(7): 85 - 99.

[14] Minniti, Maria and Wim Naude (2010) What Do We Know About The Patterns and Determinants Of Female Entrepreneurship Across Countries? European Journal Of Development Research 22(3): 277-293.

[15] Nordman, Christopher J. Dan Julia Vaillant (2012) Why Are Female Informal Entrepreneurs Less Successful Than Men? Evidence From Madagascar. https://editorialexpress.com/cgi-bin/conference /down load. cgi?db_name $=$ csae20 12 \&paper_id $=563$

[16] Aslam, Sumaira; Madiha Latif and Muhammad Wasim Aslam (2013) Problems Faced By Women Entrepreneurs and Their Impact On Working Efficiency Of Women In Pakistan. Middle-East Journal Of Scientific Research 18(8):1204-1215

[17] Batra, Geeta and Hong Tan (2003) SME Technical Efficiency and Its Correlates: Cross-National Evidence and Policy Implications. World Bank Institue Working Paper.

[18] Bhasin, Vijay (2009) Determinants Of Technical Efficiency Of Women Entrepreneurs In The Food Processing Entreprises In Cape Coast. Ghana Policy Journal (3), Pg 22-47.

[19] Heilbunn, Sibylle; Shai Rozenes and Gad Vitner (2011) A DEA Based Taxonomy To Map Successful Smes. International Journal Of Business And Sosial Science 2(2) Pp.232-241.

[20] Charoenrat, Teerawat; Charlie Harvie and Wannapa Naburana (2013) Measuring The Technical Efficiency Of Thai Manufacturing Smes: A Comparison Of Parametric and Nonparametric Approaches. Cambridge Business and Economics Pp. 1-24.

[21] Purwanto, Danny Manongga and M.A. Ineke Pakereng (2014) Efficiency Of Small and Medium Sized Tofu Enterprises (SME) In Salatiga Using Data Envelopment Analysis (DEA). International Journal Of Computer Application 91(12): 44-50.

[22] Kementerian Negara Koperasi dan Usaha Kecil dan Menengah Republik Indonesia (2008). Undang-Undang Republik Indonesia Nomor 20 Tahun 2008 Tentang Usaha Mikro, Kecil Dan Menengah.

[23] Coelli T.J. (1996). A Guide To DEAP Version 2.1: A Data Envelopment Analysis (Computer) Program. CEPA Working Papers No.8/96. Departement Of Econometrics University Of New England Armidale, NSW.Australia. http:www.une.edu.au/econometrics/ cepawp.htm.

[24] Charnes, A; Cooper, W and Rhodes, E (1981) Evaluating Program And Managerial Efficiency: An Application Of Data. Management Science (Pre-1986) 27(6) Pg. 668.

[25] Alvares, R. and Crespi, G. (2003) Determinant Of Technical Efficiency In Small Firms, Netherland. Small Business Economics 20: 233-244.

[26] Cooper, William W.; Lawrence M. Seiford; and Kaoru Tone (2006) Introduction To Data Envelopment Analysis and Its Uses. Springer Science and Business Media, Inc. 